\title{
ОСОБЛИВОСТІ ВИКОРИСТАННЯ ІКТ НА УРОКАХ МИСТЕЦТВА
}

\begin{abstract}
Анотація. У статті розглянуто реалізацію індормаційно-комунікативних технологій на уроках мистецтва. Обгрунтовано важливість застосування сучасних комп'ютерних засобів у навчальній шкільній практиці. Зазначено, що впровадження ІКТ у навчальний процес сучасного школи відкриває перспективи для розвитку творчості здобувачів освіти. Виокремлено та проаналізовано компютерні програми, мобільні додатки та музичні лабораторії, які можна ефективно застосовувати на уроках мистецтва у початковій школі під час офрфлайн та онлайн навчання. Окреслено їх варіативність у практичному застосуванні. що сприятиме урізноманітненню сучасних уроків мистецтва.
\end{abstract}

Ключові слова: інформаційно-комунікаційні технології (ІКТ), урок мистецтва, музичні комп'ютерні програми, лабораторії, мобільні додатки, музичні застосунки.

Shpitsa Roksolana, Titova Viktoriia Boris Grinchenko University of Kyiv

\section{THE FEATURES OF THE USE OF ICT IN ART LESSONS}

Summary. The article considers the implementation of information and communication technologies in art lessons. The importance of the use of modern computer tools in educational school practice is substantiated. It is noted that the introduction of ICT in the educational process of modern schools opens up prospects for the development of creativity of students. Computer programs, mobile applications and music labs that can be used effectively in primary school art lessons during offline and online learning are identified and analyzed. Among them are: multimedia graphic editor Crayola Art-Studio, MediBang Paint, online tool Crello, use of karaoke from YouTube video hosting, constructor for creating puzzles (Online puzzle), mobile application Piano, online music service Kapprome, Kahoot and music laboratory - Chrome Music Lab. Their variability in practical application is outlined. It allows you to effectively form a lasting cognitive interest in works of art, phenomena, processes, skills and abilities to improvise, develops musical abilities, initiative and independence of students in search of ways to solve problems. It is noted that the use of ICT in the educational process will contribute to the diversification and modernization of art lessons. Thus, in general education institutions during primary school lessons, ICTs help not only to organize the educational process, but also to provide feedback during distance learning. They are used at all stages of the lesson: explanation of new material (audio-video materials about composers, interesting facts about artists' work, etc.), consolidation of artistic information, repetition and control of knowledge. The use of ICT in practical activities in art lessons in primary school takes time. Their application allows you to effectively form a lasting cognitive interest in works of art, phenomena, processes, skills and abilities to improvise, develops musical abilities, initiative and independence of students in search of ways to solve problems. However, the arsenal of existing programs, applications, services is enriched every year, so it is important to choose those that will be interesting for primary school age and effective in use.

Keywords: information and communication technologies (ICT), art lessons, music computer programs, laboratories, mobile applications, music applications.

$\Pi$ остановка проблеми. Одним з пріоритетів вітчизняної державної політики сьогодення $є$ активне впровадження сучасних інформаційно-комунікативних технологій (IКT) в усі сорери життя, зокрема й у освітню також. Цьому сприяе реформування освітньої системи «Освіта.Україна XXI», внесення змін до закону «Про освіту», Державного стандарту початкової освіти та реалізації Концепції Нової української школи.

Індорматизація та комп'ютеризація проявляеться у всіх сфрерах людської діяльності, зокрема це особливо стало відчутним під час паднемії COVID-19. Відповідно використання сучасних IКТ набули ще більшої актуальності через вимушене використання онлайн навчання. Така ситуація вплинула й на використання IКТ у площині проведення сучасних уроків 3 мистецтва. Беззаперечна потреба в їх застосування $\epsilon$ на часі, оскільки сучасна школа повинна готувати дитину до гнучкості в інформаційно-глобалізованому світі. Цілком очевидно, що використовуючи тільки традиційні інформаційно-комунікативні технології, вирішити цю проблему неможливо.
Відтак, для практичного використання на уроках мистецтва у початкових класах актуальними є сучасні інформаційно-комунікаційні технології, нестандартні музичні компютерні програми, лабораторії, мобільні додатки та музичні застосунки, які можна використовувати не тільки у навчальному процесі офрлайн, але й під час дистанційного навчання. Незважаючи на широкий пласт наукових досліджень 3 даної проблематики потребуе уточнення та грунтовнішого аналізу використання сучасних IКТ на уроках мистецтва в початковій школі в умовах дистанційної освіти.

Аналіз останніх досліджень і публікацій. Проблема використання IКТ у педагогічній сфеpi не $є$ новою, однак в зв'язку зі світовою пандемією та перехід на дистанційне навчання набула більшої актуальності. Питанню застосування інфрормаційних технологій у навчальному процесі, аналізу педагогічного потенціалу їх використання присвячені праці О. Алексєева, Т. Коваль, В. Лапінського, М. Лапчика, А. Яцишин та ін. Сучасні можливості ІКТ у своїх працях розглядають вітчизняні науковці В. Биков, О. Бондарен- 
ко, Я. Булахова, Б. Гершунський, В. Заболотний, А. Зубов, Г. Козлакова, О. Міщенко, Н. Морзе, О. Пінчук, О. Шестопал та інші. Серед закордонних вчених виокремлюємо наукові розвідки Е. Венгера, Є. Патаракіна, О. Рона, К. Свона, В. Тініо, М. Фенгчуна. У copepi музичної педагогіки важливе місце займають роботи О. Балабана, С. Кишакевича, В. Штепи та ін. Проблема доцільності використання комп'ютера у навчанні молодших школярів, технології проектування дидактичних ситуацій 3 використанням комп'ютера розглядається вченими В. Андрієвською, В. Денисенко, А. Коломієць та О. Кравчук. Серед вчителів-практиків, які вивчають зазначену проблематику виділяемо методичні розробки О. Голуба, Д. Каташинського, О. Побірченко та ін.

Мета статті - уточнити значення інформаційно-комунікативних технологій у освітньому процесі та запропонувати музичні програми, застосунки, лабораторії, додатки для застосування їх на уроках мистецтва.

Виклад основного матеріалу дослідження. Інформатизація сучасного суспільства впливає на чільність використання IКТ у освітній системі. Вона стає прикметною ознакою нашого часу. В умовах редрормування вітчизняної освіти особливої уваги потребуе початкова ланка освіти.

На думку Г. Лаврентьєвої [1; 3], необхідність використовування ІКТ у початковій школі повинна розглядатися через призму психологічних особливостей молодших школярів. Авторка зазначає, що застосування різних засобів ІКТ у навчанні дітей молодшого шкільного віку має позитивний педагогічний ефрект. Однак, варто пам'ятати про психофрізіологічні особливості дитини цього віку і частково використовувати IКТ на уроках.

В свою чергу, Ю. Машбиць [4, с. 134] вважає, що інформаційно-комунікаційні технології повинні стати не додатковим засобом у навчанні, а невід'ємною частиною цілісного навчального процесу. Автор переконаний, що вони підвищують ефрективність навчання і максимально сприяють всесторонньому розвитку інтелектуальної, емоційної і особової сфер дітей молодшого шкільного віку

Вітчизняна дослідниця О. Рибалко у своїх наукових розвідках вказуе на позитивний вплив застосування ІКТ на уроках у початковій школі. Авторка переконана, що застосування IКT сприяти покращенню результатів учіння (знань, умінь, навичок), позитивно впливають на психічний розвиток учнів початкових класів (спостережливість, пам'ять, уява, воля, почуття, характер) та вихованість [9, с. 19]. Вона вважає, що інформаційні технології дозволяють створити більш яскраве інтерактивне середовище навчання з відповідними можливостями для учня.

На думку науковця В. Могильової [5, с. 110], саме спілкування 3 комп'ютером чи використання мобільних додатків викликає у дітей жваве зацікавлення. Однак використання IКТ зводиться не лише до ігрової складової навчального процесу. Основна мета - навчальна. Авторка переконана, що таке зацікавлення лежить в основі пізнавальна мотивації молодшого школяра, довільності пам'яті та уваги.

Розглянувши різні точки зору сучасних науковців зазначимо, що IКТ - це потужний інстру- мент для одержання учнем інформації, ефрективний засіб підвищення інтересу до навчання, а також мотивації, наочності та науковості. Вважаємо, що популярність використання IКТ у освітньому процесі зростає у зв'язку з інформатизацією нового покоління дітей і не уявляють своє життя без гаджетів. Не є винятком і система початкової мистецької освіти. Саме викладання предметів художньо-естетичного циклу пов'язане 3 оперуванням різноманітною індрормацією (звук, зображення, відео та ін.). Як правило, вчителю мистецтва вже пропонуеться готова програмована продукція, однак залишається потреба у її урізноманітненні. Як правило, на уроках мистецтва використовуються музичні енциклопедії, навчальні й тренувально-закріплюючі програми. Застосування ІКТ під час викладання мистецьких дисциплін дозволяе пришвидшити передання навичок, культури, досвіду, а також підвищити якість навчання та освіти.

Сучасні науковці О. Пометун та Л. Пироженко вважають, що використання IКТ в навчальновиховному процесі дає можливість учням отримувати велику кількість інформації та сприяе підвищенню інтересу до вивчення мистецтва. Комп'ютерні технології дають змогу здійснювати художньо-творчий розвиток молодшого школяра завдяки впровадженню в систему початкової мистецької освіти комп'ютерних технологій, що передбачає довільний вибір варіантів навчальних програм й забезпечення едрективного педагогічного керівництва в процесі комунікативної взаємодії щодо формування системи музично-художніх знань у школярів [8; 9].

Відтак, у загальноосвітніх навчальних закладах під час проведення уроків в початковій школі, IКT допомагають не тільки організувати навчально-виховний процес, але й забезпечити зворотній зв'язок під час дистанщійного навчання. Вони використовуються на всіх етапах уроку: пояснення нового матеріалу (використовуються аудіо- відео- матеріали про композиторів, цікаві фракти про творчість художників тощо), закріплення мистецької інбборлацї̈ (для розроблення завдань з мистецтва використовуються Online puzzle, Онлайн сервici LearningApps, MediBang Paint), повторення та контроль знань (застовування сервісу Kahoot та музичної лабораторії Chrome Music Lab).

Розглянувши різні точки зору науковців стосовно даної проблематики, вважаємо за доцільне виокремити музичні програми, програми для малювання, мобільні застосунки, редактори, лабораторії, додатки, які пропонуемо використовувати на уроках мистецтва у початковій школі.

Одним 3 найпростіших та цікавих для учнів 1-4 класів є мультимедійний графічний редактор Crayola Art-Studio. Він застосовуеться як для первинного ознайомлення молодших школярів 3 роботою на комп'ютері, так і в подальшій навчальній мистецькій діяльності на уроках. За допомогою зазначеного редактора вивчаються основи кольорознавства та правйла композиції під час створення малюнків. Його доцільно застосовувати на уроках, коли школярі вивчають теплі та холодні, монохромні, ахроматичні та хроматичні, споріднені, контрастні, споріднено-контрастні кольори. Також при створенні нарюрморту чи пейзажу, чи абстрактної картини. 
Інтерес на уроках мистецтва в учнів викликае й програма MediBang Paint. Ï̈̈ пропонуемо використовувати для створення коміксів і малювання (До прикладу: учням пропонувалося прослухати музичний твір, а потім зобразити інструменти, звучання яких почули діти). Також, використовуючи iii, учні мають змогу робити фотошопи портретів відомих художників та музикантів, осучаснюючи ïx. Не менш цікавим для учнів стане фоторімейк відомих картин, які вивчаються на уроці.

Вивчаючи питання застосування IКТ на уроках мистецтва, науковці Т. Мочан та I. Майборода пропонують активно використовувати Windows MovieMaker. Вони зауважують, що завдяки даному програмному забезпеченню, учні можуть робити відеомонтаж. На думку авторів, ця програма має додаткові можливості, які вбачають у: створенні школярами слайд-шоу зі зображень відомих картин художників, своїх авторських малюнків (арт-портфоліо), додавання свого голосу у відео до пісні, яку виконуе учень, тощо. Відтак, комп'ютер стає незамінним та універсальним пристроєм для створення на уроці мистецтва творчої атмосфери шляхом використання музичного супроводу [7, с. 98].

Не менш важливим, на думку авторів, є використання графрічного редактору Microsoft Paint. Дослідники переконані, що зручний інтерфейс сприяе активному його застосуванню на уроках. Як зазначають дослідники, даний редактор дозволяе просто та швидко створювати малюнки, комбінувати та редагувати їх. В даній програмі можна використовуючи базові набори інструментів та графічних примітивів. За допомогою даної компютерної програми, учні мають змогу створити картини пензлем (мишкою), олівцями, фрломастерами, чи навіть кольоровою крейдою. Діти можуть також обирати різнокольоровий папір на якому створюють малюнок, в залежності від бажання [7, с. 9; 8]. До прикладу, вивчаючи тему «Казкові персонажі» («Мистецтво» 3 клас), можна запропонувати за допомогою даного графічного редактору створити аплікацію свого улюбленого казкового героя.

Підтримуючи погляди зазначених науковщів стосовно доцільності використання вищеозначених комп'ютерних програм, пропонуемо для урізноманітнення діяльності учнів на уроці мистецтва використовувати також онлайн інструмент Crello. 3 його допомогою, школярі молодшого шкільного віку можуть створювати зображення, анімації та відео. А вивчаючи теми про театральне мистецтво, виникнення опери, значення мюзиклів в сучасному мистецтві, з допомогою вчителя вони можуть розробляти плакати та афріші. Зазвичай, дана програма використовувалася на уроках мистецтва для проєктної командної роботи. А виконання завдань в групах з її застосуванням на уроках мистецтва стає набагато цікавішим та підвищуе інтерес учнів до вивчення мистецтва.

Незамінним та одним 3 найвживаніших у практичній діяльності $е$ використання караоке з відеохостингу YouTube. Його застосування полегшуе виконання пісні та вдосконалюе музичні навички молодших школярів. Учні можуть виконувати пісню проспівуючи зі словами, або слухаючи мелодію та зорово проглядаючи текст співаючи на морморандо (проспівуючи мелодію без слів). Це допомагае не тільки запам'ятати текст, але й покращити чистоту інтонування та вдосконалити слухові навички учнів початкової школи.

Для образного сприймання учнями мистецької інформації та портретів митців, вважаемо за доцільне використовувати на уроках конструктор для створення пазлів ONLINE PUZZLE. 3 допомогою вчителя, учні можуть створити портретпазл композитора, музичний твір якого вони вивчали на уроці. Таке завдання активізуе, сприяе візуальному запам'ятовуванню митця та покращуе сприйняття мистецької інформації.

Цікавим у застосуванні є мобільний додаток Piano. Використовуючи його на уроці, учні можуть обирати різні мелодії та створювати до них власні імпровізації. Також візуально вони краще засвоюють нотну грамоту, оскільки гра на віртуальному фортепіано не лише розвивае музичний слух, але й допомагає вивчити позначення нот буквами (наприклад: до - C, pe - D тощо) Також завдяки даному мобільному застосунку, школярі знайомляться не лише з розміщенням нот на нотоносці, але й вчаться знаходити їхні відповідники на клавіатурі віртуального музичного інструменту.

Для закріплення мистецьких знання, рекомендуемо на уроках мйстецтва використовувати онлайн сервіс Kahoot. Його застосування створюе змагальний ефект та активізуе увагу школярів. Разом з тим, кожен учень бачить свій рейтинг відповідно до обраних відповідей на питання стосовно тіеї інформації, яка вивчалася на уроці.

Створювати інтерактивні вправи, які урізноманітнюють навчальний процес дозволяе онлайн cepвic - LearningApps. Вiн має зручний інтерфейс та простий у використанні. З його допомогою можна розробляти завдання, в яких потрібно поєднати портрет композитора та аудіо фрагмент його композицій, назву музичного інструментального твору та прізвище митця, тощо. Учні із задоволенням виконують як індивідуальні, так і групові завдання, створені за допомогою зазначеного сервісу. А його варіативна складова робить його часто вживаним на уроках мистецтва.

Велику популярність серед учнів початкових класів має музична лабораторія - Chrome Music Lab. Вона включаe 12 тематичних ігрових додатків-експериментів, кожен 3 яких допомагае у формуванні певних музичних навичок. Учні можуть створювати власні мелодії, імпровізувати, виконувати ритмічні побудови, тощо. Зазначена музична лабораторія - універсальна. Її можна використовувати відповідно до будь-якої теми. Також вона стане у нагоді під час проведення інтегрованих уроків мистецтва з математикою, оскільки за допомогою одного з експериментів («Кандинський) можна почути як звучать намальовані учнями геометричні фігури.

Ще однією не менш важливою е навчальна програма «РaperOne». Вона дозволяе школярам малювати так само, як і на папері. Також вона має функцію створення малюнку на основі фотографії. Таким чином, учні мають додаткові підказки. В цій програмі вони можуть не лише імпортувати фотографії для виконання малюнку, але й переглядати їх в напівпрозорому режимі.

При застосуванні на уроках мистецтва у початковій школі зазначених програм, сервісів, мо- 
більних застосунків та лабораторій, в учнів розвивається: вміння аналізувати твори мистецтва, активізуеться увага, покращуеться уява та креативність, здатність до типізування та структурування отриманої мистецької інформації, розвивається відчуття форми, контрастів, динамічних відтінків музичних творів та творів образотворчого мистецтва, стимулюеться бажання працювати як самостійно, так і в команді, підвищуеться рівень мистецької компетентності молодшого школяра та вміння застосовувати отримані мистецькі знання на практиці.

Активне використання IКT на уроках мистецтва дає змогу здобувачам освіти оволодіти мовою музики, сприяе розвитку мистецької грамотності за допомогою комп'ютера, планшета чи гаджетів, розвиває творчі здібності, художньо-образне мислення та інформаційну культуру, збагачуе знання, вміння, навички, які учні вміло застосовують на практиці. Також воно сприяе активізації в навчальній діяльності, сприяе оригінальному виконанню творчих завдань та створює можливість для самовираження індивідуальності школяра через різні види мистецтва. Відтак, використання ІКТ на уроках мистецтва робить ї цікавими та сучасними.

Висновки. Використання IКT у практичній діяльності на уроках мистецтва у початковій школі потреба часу. Їх застосування дозволяе ефекктивно фрормувати стійкий пізнавальний інтерес до творів мистецтва, явищ, процесів, уміння і навички імпровізувати, розвиває музичні здібності, ініціативність і самостійності учнів у пошуках способів розв'язання поставлених завдань. Однак, арсенал існуючих програм, додатків, сервісів 3 кожним роком збагачуеться, тому важливо обирати ті, які будуть цікаві для молодшого шкільного віку та едективні у використанні.

\section{Список літератури:}

1. Андріевська В., Олефіренко Н. Мультимедійні технології у початковій ланці освіти. Інфорлаційні технологїі і засоби навчання. 2010. № 2(16). URL: http://journal.iitta.gov.ua/index.php/itlt/article/view/228/214

2. Білоусова Л.І., Олефіренко Н.В. Дидактичний потенціал цифрових освітніх ресурсів для молодших школярів. Освітні технологї̈ та суспільство. 2013. № 1(16). С. 586-598. URL: http://ifets.ieee.org/russian/ depository/v16_i1/pdf/14.pdf

3. Лаврентьєва Г.П. Психолого-педагогічні аспекти використання ІКТ в початковій школі. Інфорлаційні технологї̈ і засоби навчання. 2012. № 3(29). URL: http://www.journal.-iitta.gov.ua

4. Машбиц Е.И. Психолого-педагогические проблемы компьютерного обучения. Москва, 1988. 167 c.

5. Могилёва В.Н. Психофизиологические особенности детей младшего школьного возраста и их учёт в работе с компьютером) : Учеб. пособие для студ. образовательных учреждений сред. проф. образования. Москва : Академия, 2007. 272 с

6. Морзе Н. Основні інформаційно-комунікаційних технологій. Київ : Вид. група ВНV, 2006. 298 с.

7. Мочан Т., Майборода I. Використання ІКТ на уроках образотворчого мистецтва в початковій школі. Педагогічні інновації: ідеї, реалї̈, перспективи. Серія "Педагогіка" : збірник наукових праць. Київ : Ін-т обдарованої дитини НАПН України, 2016. Випуск 2(17). С. 95-99.

8. Пометун O.I., Пироженко Л.В. Сучасний урок. Інтерактивні технології навчання : Наук.-метод. посібник. Київ : А.С.К., 2004. С. 192.

9. Рибалко О.О. Молодший школяр і комп’ютер. Колn’ютер у школі та сілӥ̈. 2010. № 5. С. 21-24.

\section{References:}

1. Andriievska V. (2010) Multymediini tekhnolohii u pochatkovii lantsi osvity [Multimedia technologies in primary education]. Information technologies and teaching aids, no. 2(16). Available at: http://journal.iitta.gov.ua/ index.php/itlt/article/view/228/214 (in Ukrainian)

2. Bilousova L.I. (2013) Dydaktychnyi potentsial tsyfrovykh osvitnikh resursiv dlia molodshykh shkoliariv [Didactic potential of digital educational resources for junior schoolchildren]. Educational technologies and society, no. 1(16), pp. 586-598. Available at: http://ifets.ieee.org/russian/depository/v16_i1/pdf/14.pdf(in Ukrainian)

3. Lavrentieva H. (2012) Psykholoho-pedahohichni aspekty vykorystannia IKT v pochatkovii shkoli [Psychological and pedagogical aspects of the use of ICT in primary school]. Information technologies and teaching aids, no. 3(29). Available at: http://www.journal.-iitta.gov.ua (in Ukrainian)

4. Mashbyts E.Y. (1988) Psykholoho-pedahohycheskye problemy kompiuternoho obuchenyia [Psychological and pedagogical problems of computer training]. Moscow. (in Russian)

5. Mohyleva V.N. (2007) Psykhofyzyolohycheskye osobennosty detei mladsheho shkolnoho vozrasta y ykh uchet $v$ rabote s kompiuterom: Ucheb. posobye dlia stud. obrazovatelnykh uchrezhdenyi sred. prof. obrazovanyia [Psychophysiological features of children of primary school age and their accounting in work with the computer: Textbook. manual for students. educational institutions environments. prof. education]. Moscow. (in Russin)

6. Morze N. (2006) Osnovni informatsiino-komunikatsiinykh tekhnolohii [Basic information and communication technologies]. Kyiv. (in Ukrainian)

7. Mochan T. (2016) Vikoristannya IKT na urokah obrazotvorchogo mistectva v pochatkovij shkoli [The use of ICT in art lessons in primary school]. Pedagogical innovations: ideas, realities, perspectives. Series "Pedagogy": a collection of scientific papers. Kyiv: Institute of Gifted Children NAPS of Ukraine, vol. 2(17), pp. 95-99.

8. Pometun O.I. (2004) Suchasnyi urok. Interaktyvni tekhnolohii navchannia: Nauk.-metod. posibnyk [A modern lesson. Interactive learning technologies: Scientific method. manual]. Kyiv: A.S.K. (in Ukrainian)

9. Rybalko O.O. (2010) Molodshyi shkoliar i kompiuter [Computer at school and family]. Kompiuter u shkoli ta simi, no. 5, pp. 21-24. (in Ukrainian) 